\title{
THE PREVENTION AND TREATMENT OF PRESSURE SORES USING AIR-SUPPORT SYSTEMS
}

\author{
By J. T. Scales, H. F. Lunn, ${ }^{1}$ P. A. Jeneid, M. E. Gillingham \\ and S. J. REDFERN
}

Patient Support Unit, Department of Biomedical Engineering, Institute of Orthopaedics

(University of London), Royal National Orthopaedic Hospital, Stanmore, Middlesex

\section{INTRODUCTION}

RECENT research has extended the understanding of the factors required for rapid healing of wounds. One of the difficulties in applying some of this new knowledge is the lack of progress in providing an alternative to the conventional hospital bed. Not only may the hospital bed fail to offer a suitable local environment for wound healing, but it may itself be the cause of tissue necrosis resulting in pressure sores. This paper describes systems of air support which provide a suitable alternative to the hospital bed.

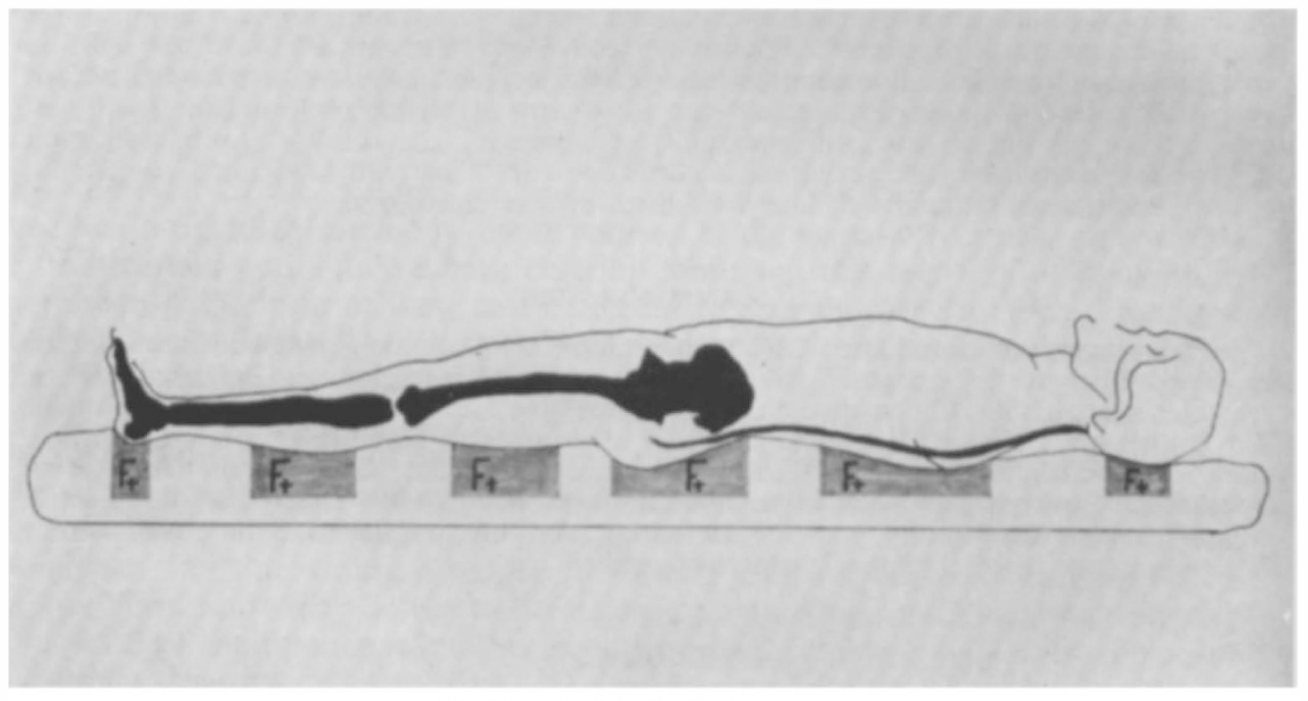

FIG. I

When a person is placed on a resilient mattress, the load per unit area is not uniform.

The soft tissues of the body encase an irregularly shaped skeleton. As a result small areas of soft tissues are compressed between the skeleton and a supporting surface. Although the load per unit area carried by these tissues will be reduced if the patient is nursed on a deformable mattress (fig. I) the magnitude of these forces is such that blood vessels are compressed and tissue damage often

${ }^{1}$ Now at the War Memorial Hospital, Lamlash, Isle of Arran, Scotland. 
ensues. In a normal person capillary pressure may be of the order of $26 \mathrm{~mm}$. $\mathrm{Hg}$ ( $0.5 \mathrm{lb}$./sq. in.), while in the debilitated or seriously ill patient it may be considerably reduced. Lindan, Greenway and Piazza (I 965), using a bed of 'springs and nails', found that the skin of a supine patient on an ordinary hospital bed may have to sustain loads up to $150 \mathrm{~mm}$. $\mathrm{Hg}(2.9 \mathrm{lb}$./sq. in.).

Redfern, Jeneid, Gillingham and Lunn (1973) studied the local pressures which can occur with various types of support systems. They included a water bed, a foam mattress, a ripple mattress and an interior sprung mattress. The maximum pressures ranged from $58 \mathrm{~mm}$. $\mathrm{Hg}(\mathrm{I} \cdot \mathrm{I} \mathrm{lb}$./sq. in.)-water bed to $\mathrm{I} 64$ mm. $\mathrm{Hg}$.(3.2 lb./sq. in.)-spring mattress.

Trumble (I930) found that when pressures of about $78 \mathrm{~mm} . \mathrm{Hg}$ (I.5 lb./sq. in.) were applied to the skin, patients complained of pain, and such pressures, while not causing collapse of larger arteries, caused collapse of the capillaries and veins. Guttmann (I 953) described the effects of pressure on the tissues as follows:

I. Transient circulatory disturbance, where the pressure has been sufficient to cause reddening of the skin and which disappears if the pressure is relieved.

2. Definite superficial and circulatory tissue damage. Reddening and congestion of the area occurs which does not disappear on decompression and which leads to induration of the tissues. Both the superficial layers and the deeper layers of the skin may be involved and there may be superficial necrosis and ulcer formation.

3. Deep penetrating necrosis. At this stage the destruction involves both subcutaneous tissues, fascia, muscle and bone. This type of sore usually develops over the sacrum and trochanters and is often more extensive than the damage to the skin would suggest.

Skin damage can also be caused by shear stresses (Guttmann I953), developing in the tissues as a result of friction between the skin and bedding. These stresses are increased in the semi-recumbent position because the patient, even when nursed on a Fowler-type bed in a semi-flexed position, may not be lying in the right attitude, i.e. the patient's centre of gravity may be such that he is tending to slide down the bed. Further, with such beds compression with loss of deformability of the mattress in the pelvic area can occur.

A further cause of skin breakdown and wound infection is the lack of evaporation of water, particularly when patients are nursed on non-vapour permeable mattresses. Burch and Windsor (1944) found that approximately $235 \mathrm{gm}$. of water is lost per sq. $\mathrm{m}$. of the body surface $/ 24$ hours at a relative humidity of 50 per cent with an ambient temperature of $24^{\circ} \mathrm{C}$.

Fluid lost from a wound may be up to ten times that rate. In the course of work on the development and evaluation of a microporous surgical dressing, Scales, Towers and Goodman (1956) found that when normal skin was covered with a microporous water-vapour permeable film, there was inhibition of bacterial growth. However, when the skin was covered with a non-water-vapour permeable film, there was an increase in bacterial growth. The coagulase positive staphylococcus was recovered from six per cent of swabs of normal skin; it was never recovered from skin under the microporous film.

When a patient is nursed for long periods on a mattress covered with a layer of impermeable material, as is current hospital practice, discomfort is caused by 
interference with thermo-regulation. During the early part of the night the patient tends to warm his skin surface until at around $36^{\circ} \mathrm{C}$ sweating occurs. This sweat does not evaporate readily and the bed linen becomes moist and feels damp. Cooling may occur later in the night when the metabolic rate falls and the patient is then roused by a sensation of cold which will be met by adding bed coverings until warmth is restored. A helpless patient may not be able to move freely or to adjust his coverings. The conventional hospital bed does not allow excess moisture to be lost through the mattress, and the micro-climate in the vicinity of the patient cannot be controlled precisely either by the ward staff or the patient. Excessive humidity, absence of free circulation of air, and fluctuations of temperature do not provide an ideal environment either for the healing of wounds or for the patient as a whole. The advantages of a thermo-neutral environment for an injured patient have been discussed by Cuthbertson et al. (I968).

Very young children and patients who are severely burnt require accurate control of their environment so that they are not stressed with heat or cold beyond the limits of their tolerance. The mortality of patients with burns of 50 per cent or more of the body surface can be reduced if heat balance is provided within a warm dry environment (Barr et al., I968; Barr, I971).

Besides the danger to the patient of pressure sores, their prevention creates a considerable nursing problem. Many patients suffering from conditions which render them particularly susceptible to pressure sores require attention every two hours. There is seldom sufficient nursing staff for this. Moving a patient during bedmaking and lifting a heavy patient on to a bedpan requires the nurse to act in a manner similar to a fork-lift truck lifting a pallet. As the musculo-skeletal system of man is poorly designed for this function, many members of the nursing profession develop chronic back-strain.

If the physiological and nursing needs are considered together, the requirements of a patient-support system are as follows:

I. Automatic deformation of the support medium to accommodate body forms.

2. Uniform thrust on maximum body surface area.

3. Minimum development of shear stresses between the system and the skin and within the tissues.

4. Evaporation of water from the support area.

5. Ability to control the temperature and humidity of the patient's environment.

6. Minimum lifting of patient and minimum liability to back-strain in nursing staff.

7. Ability to adjust the attitude and the contour of the patient by mechanical means.

8. Ease of disinfection of the equipment soiled by the patient.

9. Mobility of equipment.

I0. Ability to provide a rigid surface for cardiac massage.

I I. Equipment designed to 'fail safe'

12. Minimum physiological complications with enforced rest

Uniform support of an irregularly shaped body cannot be achieved by compressing the supporting medium. The supporting medium must conform to the individual body form. This conformation can only be achieved by the use 
of a fluid. 'A fluid consists of particles that move freely amongst themselves, so as to give way before the slightest pressure. Fluids are divided into liquids which are incompletely elastic and gases which are completely so.' If a liquid system is used, it is not possible to adjust the contour or attitude of the patient. Further, the weight of the liquid imposes certain constructional problems, both with the equipment and the floor of the building in which it is housed.

It occurred to one of us (Scales, I96I) that a body could be uniformly supported by temperature-controlled air at pressures which would not cause undesirable physiological changes and that a patient support system could be developed which would meet the requirements stated above (fig. 2).

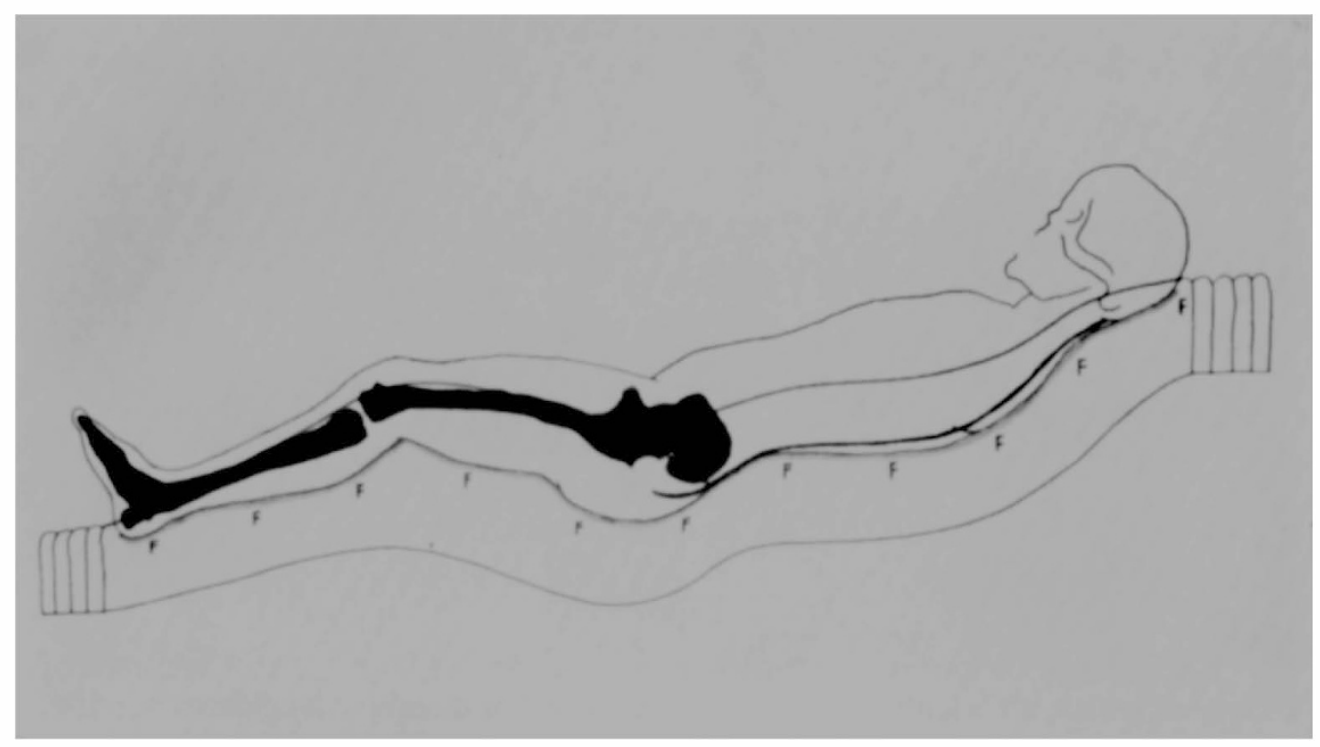

FIG. 2

When a person is supported on air, there is substantially uniform thrust per unit area.

\section{HIGH AIR LOSS SYSTEM-LEVITATION}

Levitation can be defined as the support of a body without visible means. The development of the Mark F6 Levitation or High Air Loss Patient Support System has been described elsewhere (Scales et al., I966, 1967, I969) (fig. 3). This High Air Loss Bed System (HALBS) involving the support of a patient on free air was developed for the early treatment of patients suffering from acute and severe burn injury. The patient is placed on the 'bed' when it is inflated with air at maximum pressure, approximately $36 \mathrm{~cm}$. (I4 in.) water gauge. The air pressure is then slowly reduced until the torso depresses the pockets along the midline of the bed and allows air to escape between the body and the upper surface of the pockets. Small weights are fitted in the tip of each pocket, assisting them to fall away when the pressure on their inner and outer surfaces equalises. It is not necessary to exceed $28 \mathrm{~cm}$. (II in.) water-gauge pressure to support the torso. Approximately 19,800 litres (700 cu. ft.) of air per minute are required with this system, which enables the following to be achieved:

I2/2-I 
I. Even pressure on the thrust area.

2. Rapid drying of exudate and accelerated formation of an eschar.

3. Control of body temperature and humidity of the immediate environment.

4. The isolation of a patient in a sterile environment.

5. Support of the torso without touching any surface.

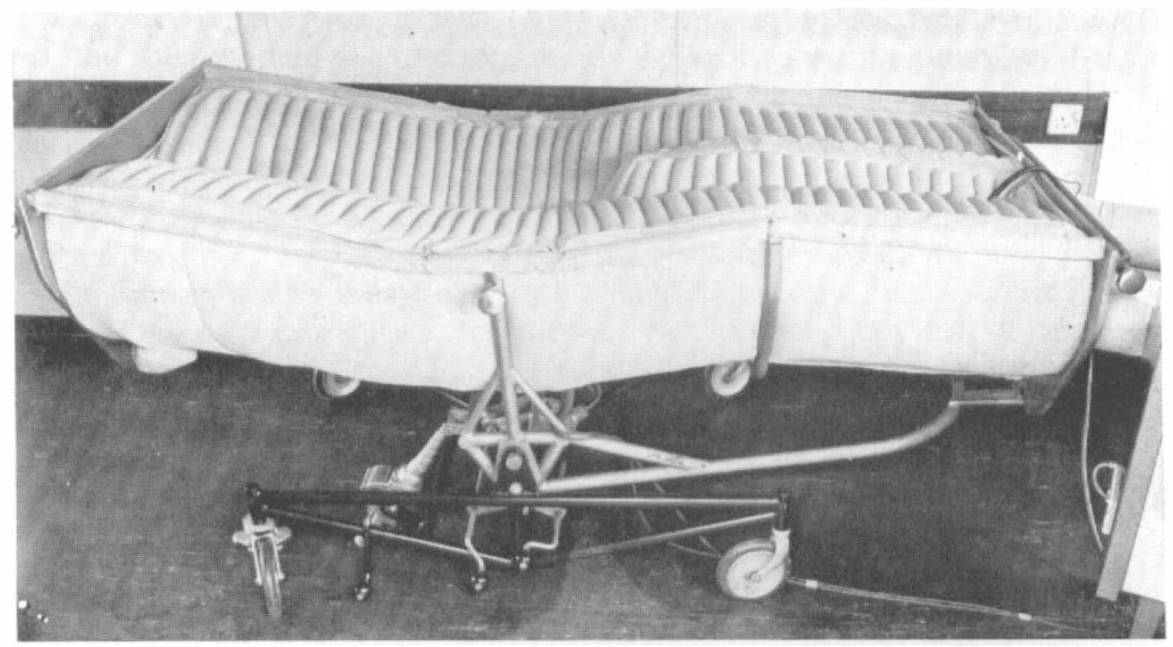

FIG. 3

Inflated High Air Loss Bed System (HALBS).

\section{LOW AIR LOSS BED SYSTEM (LALBS)}

For the later stages of treatment of burn injury and for the management of other categories of patients who are confined to bed and require long-term nursing, a Low Air Loss Bed System has been devised by interposing a suitable flexible vapour permeable film between the skin and the air. This enables the volume of air and hence the size of the blower unit to be substantially reduced.

General Description of System. A mobile blower unit situated adjacent to the 'bed' (fig. 4) supplies temperature-controlled air at up to $36 \mathrm{~cm}$. (I4 in.) water-gauge pressure measured in the air sacs. The air from the fan is fed into a chamber in the mobile blower unit containing a I000-watt heater which is controlled by a digital temperature controller mounted on the control panel of the blower unit. The pressure in the air sacs is adjusted by five throttle valves sited on the front panel of the blower unit. Five $3.8 \mathrm{~cm}$. ( $I_{2} \frac{1}{2}$ in.) flexible hoses enclosed in a $12.7 \mathrm{~cm}$. ( 5 in. diam.) flexible cover lead to the support area which consists of five groups of vapour permeable air sacs each $28 \mathrm{~cm}$. (II in.) in height when inflated. The pressure in the delivery tube to each group of sacs is shown on the gauge adjacent to the appropriate valve on the blower unit. Each sac is carried on a feeder bar. Any one sac can be changed without disturbing the patient. There are three hinges in the frame carrying the five air sections. The seat section is fixed. The hinges are sited so that the two back sections can be raised on the fixed seat section by bellows. The knee is flexed by bellows, which 
raise the thigh and calf/foot section. The contour frame pivots on the mobile chassis to allow the attitude of the contoured patient to be adjusted by means of an electric motor (fig. 5). The top surfaces of the padded air feeder bars are $53.3 \mathrm{~cm}$. (2 I in.) from the floor. Attachments are provided on the frame to allow octagonal traction and suspension apparatus to be fitted (fig. 4).

Clinical Use of the Low Air Loss Bed System. The LALBS is labour saving. All nursing care can be carried out without lifting the patient. A bedpan can be inserted by reducing the pressure in the air sacs supporting the patient's buttocks-seat section-and sliding the pan under the patient (fig. 6). This requires minimum effort by the nurse and causes no discomfort to the patient.

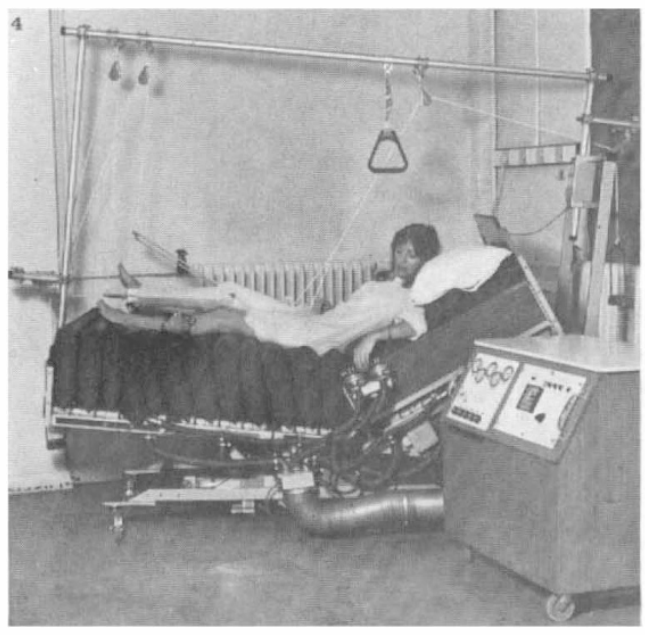

FIG. 4

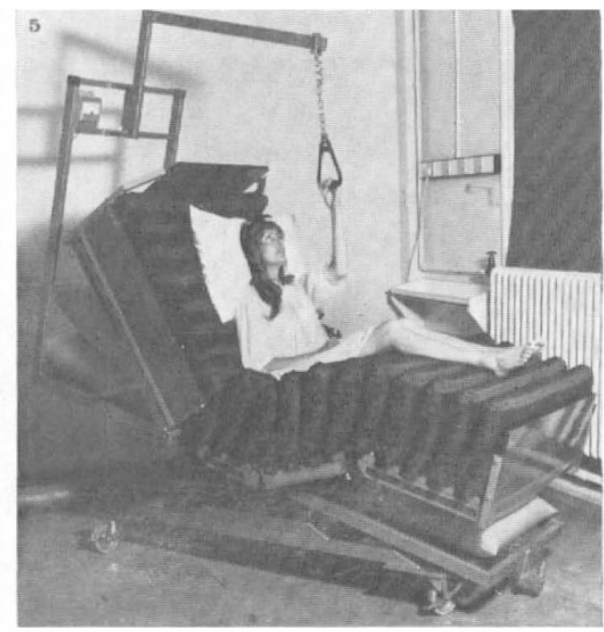

FIG. 5

Fig. 4.-Mk 4B Low Air Loss Bed System (LALBS)-fitted with Octagonal traction apparatus. The blower is alongside the bed.

Fig. 5.- Mk $4 \mathrm{~B}$ showing the bellows controlling the contour of the bed. The attitude frame is in the foot down position.

The even distribution of body weight eliminates the routine care of pressure areas. Most procedures can be carried out by one nurse and the mechanical attitude adjustment allows her to slide the patient off the foot end of the bed into a wheelchair. The contouring mechanism allows the patient to be sat up in bed with feet raised if necessary, without being lifted (fig. 5). The attitude is adjusted to head down or foot down positions for short periods twice daily to reduce the risk of urinary or circulatory complications of recumbency (fig. 7). Bedmaking is eliminated as only one sheet is used to cover the patient and laundry costs are reduced to a minimum. Hygiene is maintained by sponging the air sacs daily with a solution of one per cent Savlon in water, the air sacs being dried in approximately Io minutes by increasing the temperature of the air supplied to the bed by $4{ }^{\circ} \mathrm{C}$. This procedure may be carried out satisfactorily without removing the patient from the bed, by washing each half of the surface of the sacs separately. The fabric of the air sacs can be laundered in a domestic washing-machine at $25^{\circ} \mathrm{C}$ 
using soap powder-not a detergent. The air sacs must be tumble dried, not spun, at a temperature not exceeding $50^{\circ} \mathrm{C}$.

The mechanical and pneumatic adjustments to the bed substantially reduce the risk of back injury to the nurse, and as the controls are within reach of the patient, they allow a degree of independence not normally experienced in a hospital bed. The nurse thus has more time to carry out more specialised nursing duties.

Physiological Studies. There is evidence (Benzinger, 1967) that when the average skin temperature is less than $33^{\circ} \mathrm{C}$ and before shivering commences, a normal subject responds to the stress of cold by an increase in oxygen uptake.

The LALBS provides a means of controlling the air temperature of the environment immediately surrounding the patient. The air temperature can be

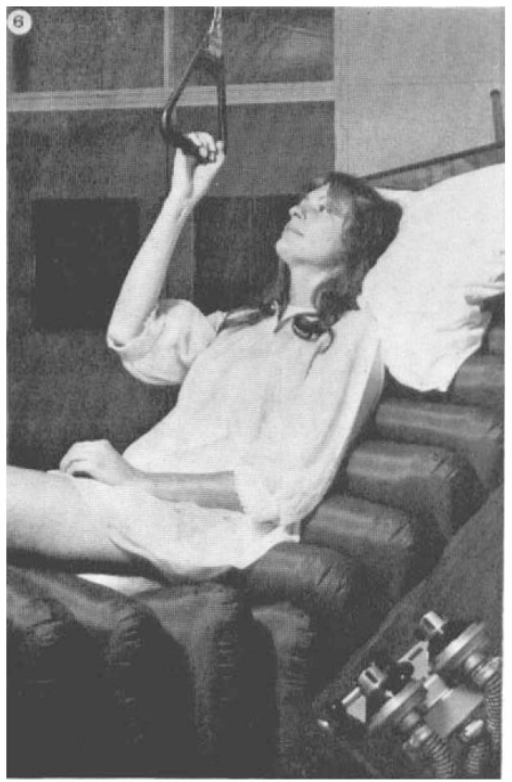

FIG. 6

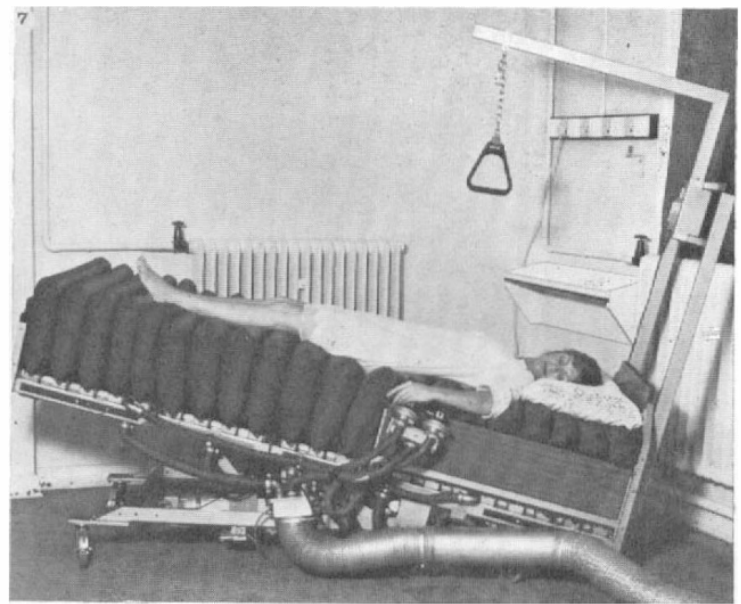

FIG. 7

Fig. 6.-Patient sitting on a bedpan.

Fig. 7.-LALBS in head down position with patient operating the controls.

adjusted to ensure that the average skin temperature does not rise above $36^{\circ} \mathrm{C}$ : the approximate temperature at which sweating is initiated.

This measure of control has been achieved despite the ambient temperature ranging from $18^{\circ} \mathrm{C}$ to $28^{\circ} \mathrm{C}$. Relative humidity has been monitored and found to vary in the room between 30 per cent to 65 per cent R.H. Measurements of the relative humidity within air sacs have shown a R.H. of approximately 30 per cent. It was anticipated that a system employing a continuous flow of warm air at this humidity might result in dehydration of the patient over the 24-hour period. Measurements of the fluid intake and output have suggested that the urinary output was in fact virtually unaltered. In a previous report (Scales \& Hopkins, I97I) the differential between fluid intake and output was found to be low and not significantly different from that obtained when patients were nursed on conventional hospital beds. The initial report was based on the routine fluid- 
balance charts maintained by nursing staff in each case. We have been able to confirm the accuracy of the initial report.

An adult male patient was receiving treatment for obesity and had been placed on a weight-reduction diet. As part of his treatment his fluid intake and output was accurately measured each day and the calorific value of his food was maintained at a constant level. For the first week he slept on a hospital bed at night and was allowed a standard amount of activity by day. For the second week he followed the same routine of diet and activity, but slept on the LALBS. For a final week he slept on the hospital bed. During the last two weeks of the trial a separate note was kept of the volume of urine passed during the day and during

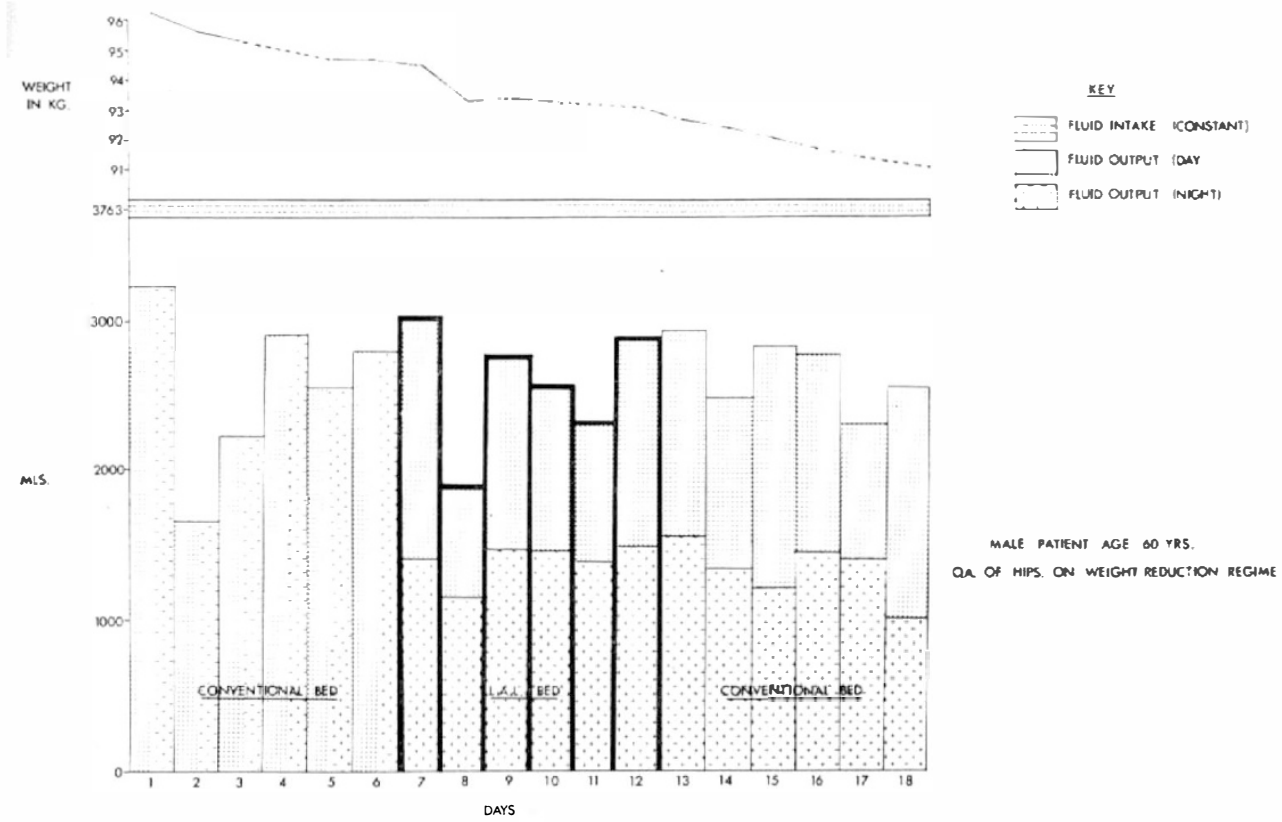

FIG. 8

Histogram showing that there is no significant evidence of dehydration when a patient is nursed either on a standard hospital bed or the LALBS.

the night. There was a slight increase of urine passed when the patient first moved on to the LALBS-this has occurred with other patients. Later during the trial periods there was no significant difference in total output (fig. 8). The volume of urine passed by night was slightly greater than that on the hospital bed.

Weighing of the bed clothes and pillows of patients nursed overnight on a conventional hospital bed showed that moisture was retained. Sheets taken from beneath a patient contained $40 \mathrm{ml}$. of water, which was removed by drying. It was found difficult to dry pillows used in posturing some patients and a loss of unly ro ml. per pillow of moisture was achieved by a similar drying process.

Clinical Results. Details of the 36 patients who were nursed on the LALBS for a total of 159 weeks are given in Table. Twenty-four of these were admitted 


\section{TABLE}

Cases nursed on the LAL bed system

\begin{tabular}{|c|c|c|c|c|}
\hline No. & Patient & Age & Diagnosis & $\begin{array}{l}\text { Length of ti } \\
\text { spent on LA }\end{array}$ \\
\hline I & H. S. & 44 & $\begin{array}{l}\text { T.B. spine. Paraplegia. } \\
\text { Pressure sores over lumbar kyphosis. }\end{array}$ & 54 days \\
\hline 2 & J. L. & 45 & $\begin{array}{l}\text { Multiple sclerosis. } \\
\text { Large pressure sores. }\end{array}$ & 33 days \\
\hline 3 & R. H. & 63 & $\begin{array}{l}\text { Rheumatoid arthritis. } \\
\text { Fractured femur. }\end{array}$ & 29 days \\
\hline 4 & J. B. & 20 & $\begin{array}{l}\text { Osteoarthritis left hip following slipped } \\
\text { femoral epiphysis. }\end{array}$ & 8 days \\
\hline 5 & C. B. & 62 & $\begin{array}{l}\text { Rheumatoid arthritis. } \\
\text { Fractured femur. }\end{array}$ & 9 days \\
\hline 6 & H. D. & 60 & $\begin{array}{l}\text { Crush fracture of spine and os calcis. } \\
\text { Fractured left femur. }\end{array}$ & 32 days \\
\hline 7 & G. S. & 48 & $\begin{array}{l}\text { Paraplegia. } \\
\text { Pressure sores. }\end{array}$ & 26 days \\
\hline 8 & A. B. & 42 & $\begin{array}{l}\text { Quadriplegia following T.B. arachnoiditis. } \\
\text { Large pressure sores. }\end{array}$ & 73 days \\
\hline 9 & R. P. & 54 & $\begin{array}{l}\text { Multiple sclerosis. } \\
\text { Pressure sores. }\end{array}$ & 28 days \\
\hline IO & L. S. & 56 & $\begin{array}{l}\text { Multiple sclerosis. } \\
\text { Sacral pressure sores. }\end{array}$ & 24 days \\
\hline I I & E. G. & 35 & $\begin{array}{l}\text { Multiple sclerosis. } \\
\text { Transverse myelitis. } \\
\text { Sacral pressure sores. }\end{array}$ & 25 days \\
\hline I2 & A. B. & 42 & $\begin{array}{l}\text { Quadriplegia. } \\
\text { Pressure sores. }\end{array}$ & 23 days \\
\hline I3 & M. B. & 46 & $\begin{array}{l}\text { Multiple sclerosis. } \\
\text { Pressure sores. }\end{array}$ & 62 days \\
\hline I4 & G. W. & 42 & $\begin{array}{l}\text { Multiple sclerosis. } \\
\text { Pressure sores. }\end{array}$ & I9 days \\
\hline I 5 & A. W. & 50 & $\begin{array}{l}\text { Multiple sclerosis. } \\
\text { Pressure sores. }\end{array}$ & 56 days \\
\hline I6 & M. B. & 46 & $\begin{array}{l}\text { Multiple sclerosis. } \\
\text { Pressure sores. }\end{array}$ & 7 days \\
\hline I7 & B. C. & 47 & $\begin{array}{l}\text { Liposarcoma right leg and pelvis. } \\
\text { Pressure sores. }\end{array}$ & 84 days \\
\hline I8 & G. W. & 42 & $\begin{array}{l}\text { Multiple sclerosis. } \\
\text { Pressure sores. }\end{array}$ & I46 days \\
\hline I9 & B. W. & 34 & $\begin{array}{l}\text { Spina bifida. } \\
\text { Pressure sores. }\end{array}$ & I3 days \\
\hline 20 & A. B. & 42 & $\begin{array}{l}\text { Quadriplegia. } \\
\text { Pressure sores. }\end{array}$ & 22 days \\
\hline $2 \mathrm{I}$ & M. B. & 46 & $\begin{array}{l}\text { Multiple sclerosis. } \\
\text { Pressure sores. }\end{array}$ & 27 days \\
\hline 22 & E. H. & 84 & $\begin{array}{l}\text { Fracture of left femur. } \\
\text { Pressure sores. }\end{array}$ & I2 days \\
\hline $\begin{array}{l}23 \\
24\end{array}$ & $\begin{array}{l}\text { L. O’S. } \\
\text { G. W. }\end{array}$ & $\begin{array}{l}60 \\
42\end{array}$ & $\begin{array}{l}\text { Osteoarthritis both hips. } \\
\text { Multiple sclerosis. } \\
\text { Pressure sores. }\end{array}$ & $\begin{array}{l}6 \text { nights } \\
38 \text { days }\end{array}$ \\
\hline
\end{tabular}




\begin{tabular}{|c|c|c|c|}
\hline No. & Patient & Age & Diagnosis \\
\hline 25 & J. C. & 74 & $\begin{array}{l}\text { Osteoarthritis of hip. } \\
\text { Total hip replacement. }\end{array}$ \\
\hline 26 & I. H. & 54 & $\begin{array}{l}\text { Osteoarthritis of hip. } \\
\text { Total hip replacement. }\end{array}$ \\
\hline 27 & B. D. & 72 & $\begin{array}{l}\text { Osteoarthritis of hip. } \\
\text { Total hip replacement. }\end{array}$ \\
\hline 28 & M. B. & 46 & $\begin{array}{l}\text { Multiple sclerosis. } \\
\text { Pressure sores. }\end{array}$ \\
\hline 29 & B. R. & 48 & Terminal carcinoma \\
\hline 30 & W. J. & $5 \mathrm{I}$ & $\begin{array}{l}\text { Multiple sclerosis. } \\
\text { Pressure sores. }\end{array}$ \\
\hline 3I & M. S. & 65 & T.B. Spine. Quadriplegia. \\
\hline 20 & C. $\mathrm{H}$. & 52 & $\begin{array}{l}\text { Osteoarthritis of hip. } \\
\text { Total hip replacement. }\end{array}$ \\
\hline 3 & A. $P$ & 59 & Rheumatoid arthritis. \\
\hline & & 42 & $\begin{array}{l}\text { Quadriplegia. } \\
\text { Pressure sores. }\end{array}$ \\
\hline 35 & G. W. & 42 & $\begin{array}{l}\text { Multiple sclerosis. } \\
\text { Pressure sores. }\end{array}$ \\
\hline 36 & D. S. & 50 & $\begin{array}{l}\text { Multiple sclerosis. } \\
\text { Pressure sores. }\end{array}$ \\
\hline
\end{tabular}

Length of time spent on LALBS

I9 days

22 days

I3 days

57 days

3 days

37 days

64 days

I6 days

4 days

12 days

Io days

Still receiving treatment

with one or more pressure sores which had failed to respond to conventional treatment. In none of these 24 patients were there any new areas of skin breakdown during the time spent on the LALBS, although nursing care did not include the standard attention to pressure areas. Several of the patients were nursed on the LALBS for more than one period. When they were transferred to standard hospital beds and conventional equipment was used for the prevention and treatment of pressure sores there were recurrences.

The following is an example of the condition of patients treated.

In 1954, A. B., a female patient aged 20 years, had tuberculous meningitis which left her with spinal arachnoiditis. She developed spondylolisthesis, flexion contracture of the hips, incontinence of urine, paraplegia and pressure sores. The pressure areas were skin grafted in 1969, but later the pressure sores recurred. She was transferred to the Royal National Orthopaedic Hospital following several months' treatment for pressure sores of both bottocks. She had gross wasting of the small muscles of both hands and the biceps; various other shoulder muscles were weak. She was nursed on the LALBS from 20.10.7I (fig. 9). The condition of the pressure sores rapidly improved (fig. I0). Autografts were applied to the pressure areas on II.II.7I (fig. II). In April 1972 the head and neck of left femur was excised to correct the deformity of the hip and allow the excision of a healed pressure sore (fig. I2). In March 1973 she was transferred to another hospital for further surgery and remained there for five months. Again she developed pressure sores despite every care being taken to prevent such a recurrence. Figure I3 shows her condition shortly after readmission in August 1973. She is again being nursed on a LALBS and her condition is improving.

\section{DISCUSSION}

Clinical trials with the LALBS have shown that the requirements necessary for an ideal patient-support system stated earlier have been met. The success in 


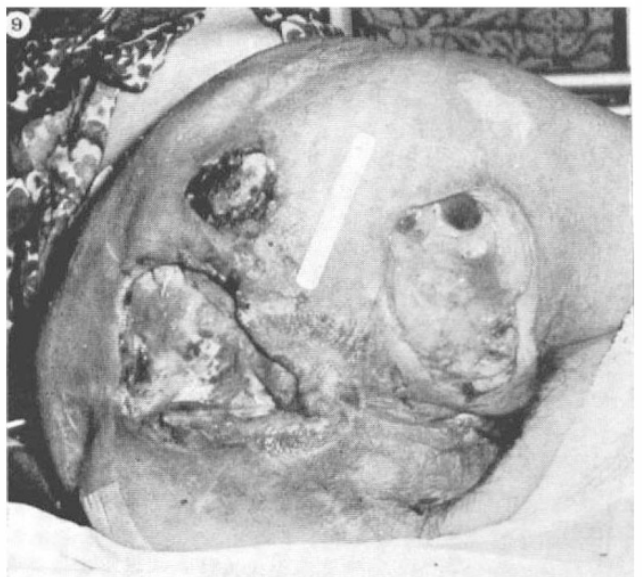

FIG. 9

Condition of pressure areas of patient when placed on the LALBS. 20.10.7I.



FIG. IO

Fig. I0.-The improvement in the condition of the pressure areas 9.I I.7I after 20 days on the LALBS.

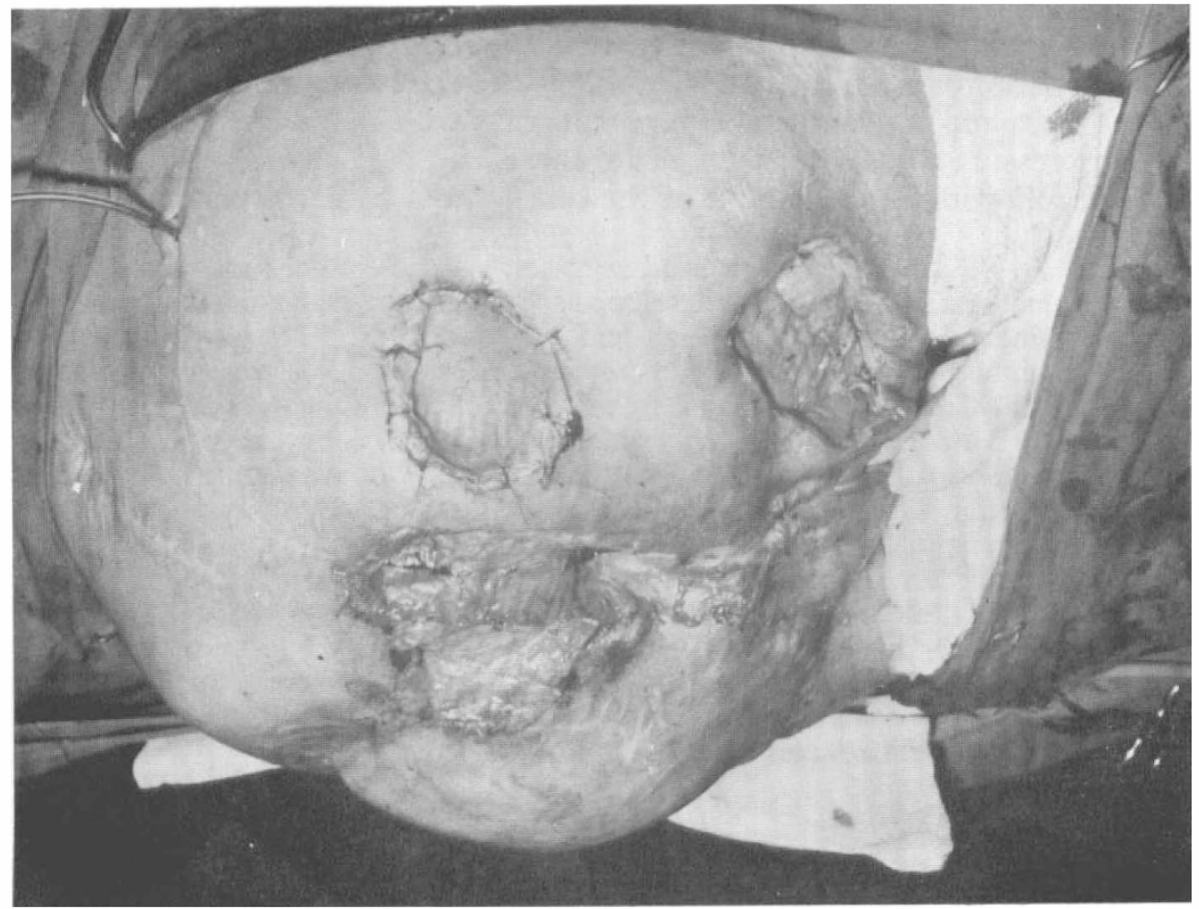

FIG. I I

Showing autografts applied. I2.II.7I. 
healing pressure sores and no pressure area treatment having been carried out on any patient suggests that the Low Air Loss Bed System provides a satisfactory method of patient support.

Local pressure on blood vessels around healing areas has been avoided (Redfern et al.). The distribution of thrust has minimised the sensation of pressure so that patients feel more comfortable and sleep more soundly, often without sedation. The results of the trial suggest that pressure sores would not have developed if this method of patient support had been used initially in that group of patients who were confined to bed by their disease.

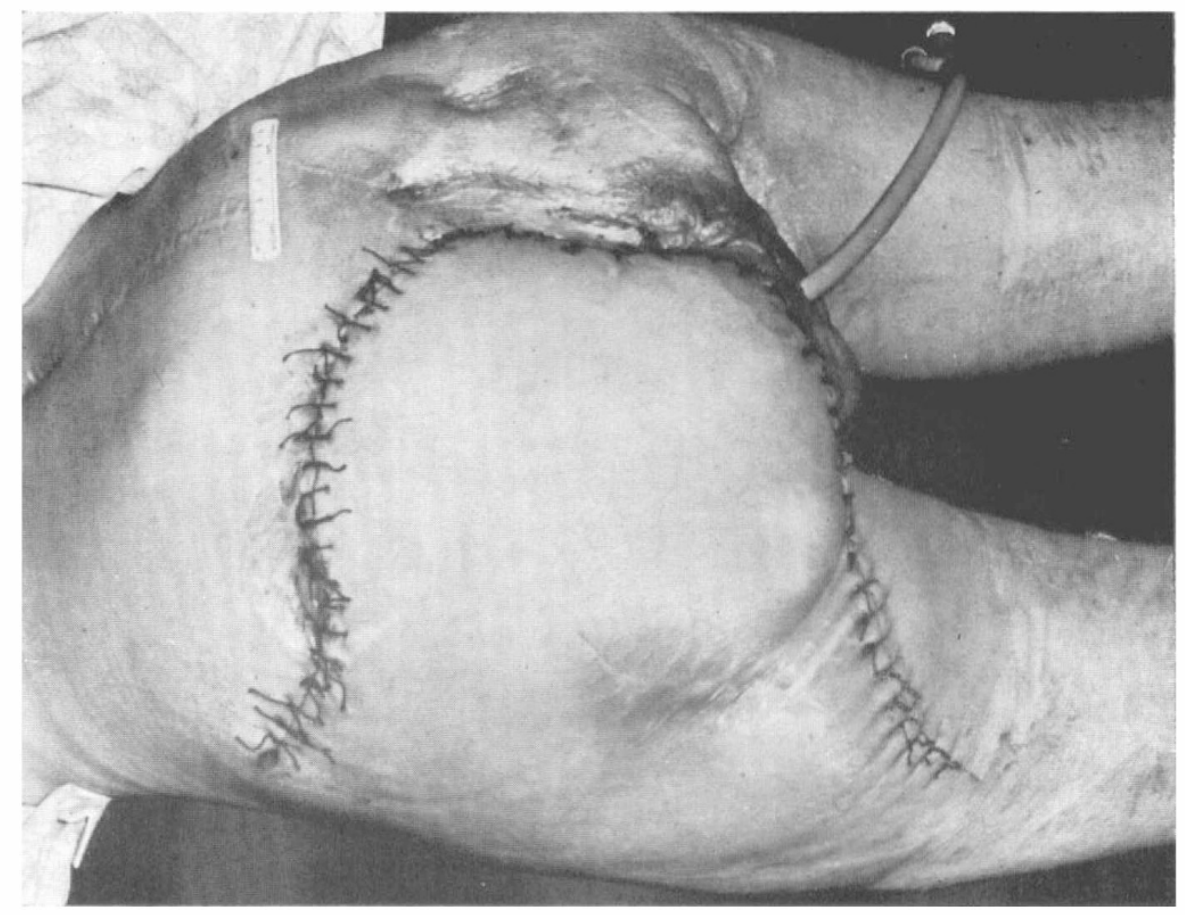

FIG. I2

Five days after excision of head and neck of left femur in April 1972.

There has been less tendency for healing tissues and regenerating blood vessels to be damaged as shear stresses have been reduced to a minimum.

Ventilation of the surface on which the patient lies is facilitated. The skin is kept dry and not chilled by evaporation because the circulating air is warmed. The excessive local humidity which might favour infection by bacterial proliferation is avoided. The support area can be considered a ventile dressing.

Control of the patient's micro-environment has removed any stress that might have been caused by the patient adapting himself to changes in room temperature and movement. It is not yet established how far maintaining thermal balance of the body contributes to an improvement in the general health of the more chronic type of patient that has been treated. In the case of small children and all severely burnt patients there is no doubt that this is proving to be a 
significant factor in their survival (Barr et al., I968; and Barr I97I). The steady environmental state with the diffusion of gases through the permeable air cells may well aid epithelisation of the healing areas which depends upon oxygen derived from the environment and the blood supply to the dermis.

Nursing staff benefit from not having to lift patients and the patients are also relieved of the discomfort of being lifted. The soft tissues of the buttocks are not damaged by insertion of a bedpan.

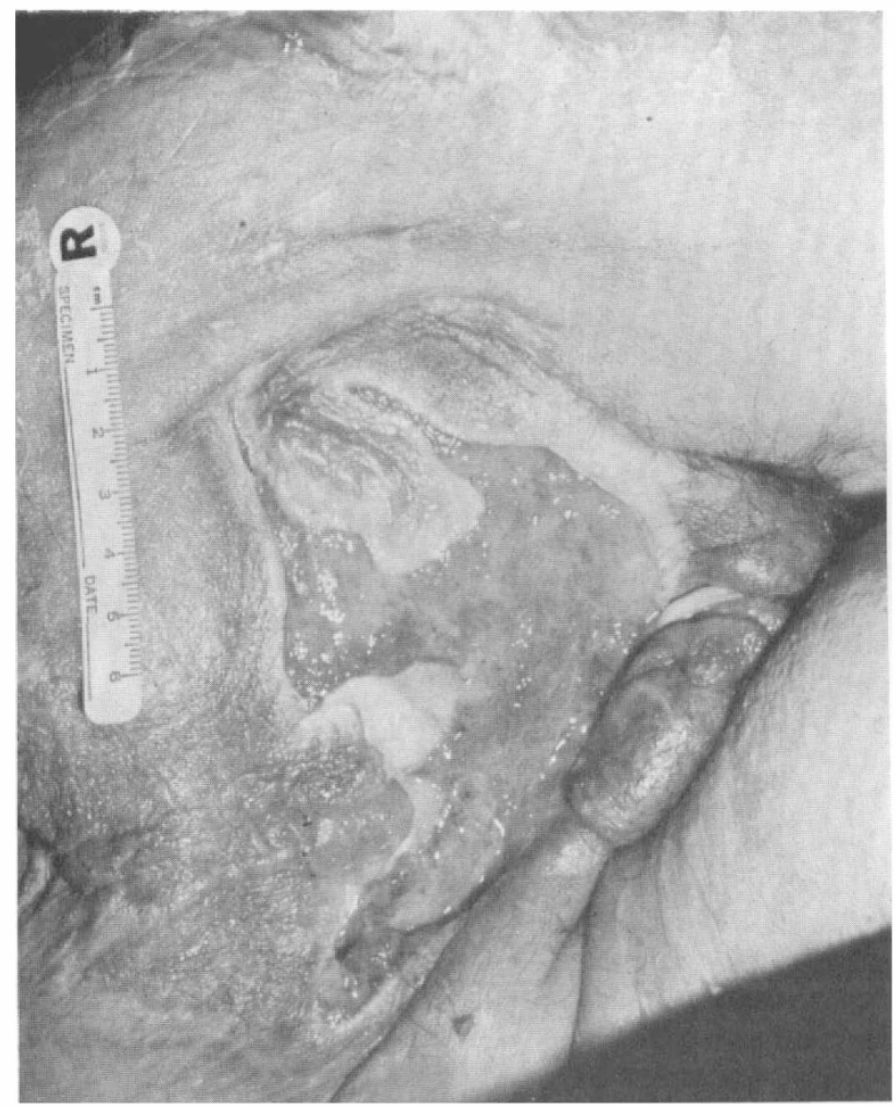

FIG. I3

Readmission in August 1973 after five months in another hospital.

The ease with which the patient can adjust the attitude and contour of the 'bed' has provided him with an increased freedom and independence. In many cases patients are able to make better use of their time during the day.

We are satisfied that the routine use of Savlon provides an easy and effective method of disinfection of the equipment.

The LALBS has been employed for the most part on a ward in which severely disabled patients have been at risk from developing pressure sores. From time to time, however, it has been necessary to transport the system to other 
parts of the hospital, such as the Accident Unit, Recovery Ward and Metabolic Unit. The air sacs have been deflated and the patient moved through the hospital on the bed without difficulty.

Acknowledgements. We wish to thank Mr. R. Wadey, Director of Research, Zimmer G. B. Group of Companies, who designed the Mark 3 LALBS in association with Messrs. Watkins and Watson Limited, who designed and supplied the Mark 4 LALBS.

We would like to acknowledge the very valuable contribution of Mr. L. A. Hopkins who took such an active part and made such important contributions to the development of the Low Air Loss Bed Systems.

We are most grateful for all the help and suggestions given in the clinical trial of the equipment by Mr. Peter Hargreaves and members of the Staff of the Department of Biomedical Engineering who have helped in a variety of ways. The cooperation of the Principal Nursing Officer, Miss $M$. O'Hare, the nursing staff and the medical staff of the Royal National Orthopaedic Hospital is much appreciated.

We wish to thank the National Research Development Corporation and the Department of Health and Social Security for grants which have made this work possible.

We wish to thank the Editors of the Lancet, Engineering in Medicine and Buchhandlung und Verlog Han Huber for their permission to publish Figures I, 2 and 3.

\section{REFERENCES}

BARR, P. O. (I97I). Svävbädd, fluidbädd och torrvärmebädd. Lakartidningen, 68, 4 I 27. Barr, P. O., Birke, G., LiljedAhL, S. O. \& Plantin, L. O. (I968). Lancet, i, I64.

Benzinger, T. H. (1967). In Les Concepts de Claude Bernard sur le Milieu Interieur. Paris: Masson.

Burch, G. E. \& Windsor, T. (I944). Arch. intern. Med. 74, 428.

Cuthbertson, D. P., Smith, C. M. \& Tilstone, W. J. (1968). Brit. F. Surg. 55, 513.

Guttmann, L. (1953). Medical History of Second World War. H.M.S.O., Surg. 2: 422.

Lindan, O., Greenway, R. M. \& Piazza, J. M. (1965). Arch. Phys. Med. 46, 378-385.

Redfern, S. J., Jeneid, P. A., Gillingham, M. E. \& LunN, H. F. (I973). Lancet, ii, 277-280.

SCALES, J. T. (I96I). Lancet, ii, I I8I.

SCALES, J. T. \& HOPKINS, L. A. (I97I). Lancet, ii, 885-888.

Scales, J. T., Hopkins, L. A. \& MuIR, I. F. K. In Pharmacological Treatment in Burns. Proc. Internat. Symposium, Milan (1968). Excerpta Medica Foundation, Amsterdam 333-342 (1969).

Scales, J. T., Hopkins, L. A., Bloch, M., Towers, A. G. \& Muir, I. F. K. (1967). Lancet, I 235 -I 240.

Scales, J. T., Towers, A. G. \& Goodman, N. (1956). Brit. med. F. ii, 962.

SCAles, J. T., Winter, G. D. \& Bloch, M. (I966). In Research in Burns, p. 266. Transactions 2nd International Congress on Research in Burns. Edinburgh: E. \& S. Livingstone Ltd.

The Shorter Oxford English Dictionary. Oxford University Press, 1964.

Trumble, H. C. (1930). Med. F. Aust. ii, 724. 